ORIGINAL ARTICLE

\title{
The risk to the United Kingdom population of zinc cadmium sulfide dispersion by the Ministry of Defence during the "cold war"
}

\section{P J Elliott, C J C Phillips, B Clayton, P J Lachmann}

See end of article for authors' affiliations

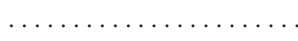

Correspondence to: Dr P J Lachmann, Academy of Medical Sciences, 10 Carlton House Terrace, London SWIY 5AH, UK; pil1000@cam.ac.uk

Accepted 12 July 2001

\begin{abstract}
Objectives: To estimate exposures to cadmium (Cd) received by the United Kingdom population as a result of the dispersion of zinc Cd sulfide ( $\mathrm{ZnCdS}$ ) by the Ministry of Defence between 1953 and 1964, as a simulator of biological warfare agents.

Methods: A retrospective risk assessment study was carried out on the United Kingdom population during the period 1953-64. This determined land and air dispersion of ZnCdS over most of the United Kingdom, inhalation exposure of the United Kingdom population, soil contamination, and risks to personnel operating equipment that dispersed $\mathrm{ZnCdS}$.

Results: About $4600 \mathrm{~kg} \mathrm{ZnCdS}$ were dispersed from aircraft and ships, at times when the prevailing winds would allow large areas of the country to be covered. Cadmium released from 44 long range trials for which data are available, and extrapolated to a total of 76 trials to allow for trials with incomplete information, is about $1.2 \%$ of the estimated total release of $\mathrm{Cd}$ into the atmosphere over the same period. "Worst case" estimates are $10 \mu \mathrm{g} \mathrm{Cd}$ inhaled over 8 years, equivalent to $\mathrm{Cd}$ inhaled in an urban environment in 12-100 days, or from smoking 100 cigarettes. A further $250 \mathrm{~kg} \mathrm{ZnCdS}$ was dispersed from the land based sites, but significant soil contamination occurred only in limited areas, which were and have remained uninhabited. Of the four personnel involved in the dispersion procedures (who were probably exposed to much higher concentrations of $\mathrm{Cd}$ than people on the ground), none are suspected of having related illnesses.

Conclusion: Exposure to $\mathrm{Cd}$ from dissemination of $\mathrm{ZnCdS}$ during the "cold war" should not have
\end{abstract} resulted in adverse health effects in the United Kingdom population.
$E_{d}^{a}$ arly in the "cold war", from 1953 to 1964, a programme of zinc cadmium sulfide (ZnCdS) dispersion tests was conducted by the British Ministry of Defence, to simulate biological attack by communist forces. Discrete dissemination of toxic biological agents over the entire country was considered a high risk for an island such as Britain. Studies were conducted in Britain, America, and Scandinavia to determine whether small particles could be widely dispersed from aircraft or vehicles. Zinc cadmium sulfide was a suitable tracer, because it fluoresces under ultraviolet (UV) light and single particles could be counted on samplers around the country.

Initially various static disseminating and recording devices were tested at ground level, followed by release from vehicles and aircraft, from which the primary threat existed. Further studies investigated release from ships in the English Channel and the Irish Sea.

When information about the trials was released in the 1990s, public concern about health risks was voiced in America and Britain, but a toxicological assessment of the dispersion tests of ZnCdS carried out by the United States Army was reassuring. ${ }^{1}$ We independently reviewed the United Kingdom trials, assessing possible human exposure to cadmium (Cd) (the presumed toxic component of $\mathrm{ZnCdS}$ ), ${ }^{1}$ and conducted a risk assessment in comparison with other sources of $\mathrm{Cd}$.

\section{METHODS}

Field trial programmes, reports, and technical papers from Porton Down ${ }^{2-36}{ }^{37}$ detailing the United Kingdom trials (most of which are, or shortly will be, available through the Public Records Office) were provided by the Defence Evaluation and Research Agency. Planned field programmes, operation dates, dissemination routes, quantities of $\mathrm{ZnCdS}$ disseminated and recovered and locations of sampling stations were described. Two internal reviews were conducted. ${ }^{38}{ }^{39}$ Ground disseminating trials each released $0.4-9 \mathrm{~kg}$ ZnCdS from either a point source, to test equipment, or a vehicle, to simulate stealth attack. In early programmes fallout was measured in Petri dishes placed at about $2 \mathrm{~m}$ intervals in a grid around the disseminator.

Not all disseminations from aircraft and ships were comprehensively recorded. Some are reported more than once, and for others (approved in field programmes) no details are available. The aircraft trials over the sea were conducted 10-50 miles off the coast at an altitude of about $300 \mathrm{~m}$. Particle fallout was monitored by cascade impactors or drum impactors located across the country. Widespread dissemination over hundreds of miles occurred.

The first trial using aircraft dissemination in 1956 released $12 \mathrm{~kg}$ ZnCdS over Porton from a hand fed Venturi unit below the aircraft. The last recorded aircraft dissemination in 1963 released $68 \mathrm{~kg}$ ZnCdS over 62 miles upwind and south west of Norwich. Other programmes, dated 1960-4, proposed dissemination by air at an unstated location (programme 23/60) and over Cardington (programmes 2/61, 24/62 and 10/63), Netheravon (programme 14/63) and Norwich (programme $2 / 64)$, but no details are available. Nine disseminations from ships are recorded in October and November 1959 and January 1963.

Abbreviations: UV, ultraviolet; $\mathrm{Cd}$, cadmium; $\mathrm{ZnCdS}$, zinc cadmium sulfide 
Table 1 Land based dissemination of ZnCdS by the United Kingdom Ministry of Defence sampled by fallout impactors at near distance $(<300 \mathrm{~m})$ and cascade impactors at 25 and 50 miles

\begin{tabular}{|c|c|c|c|c|c|}
\hline $\begin{array}{l}\text { Field } \\
\text { report } \\
\text { FR }\end{array}$ & $\begin{array}{l}\text { Material } \\
\text { disseminated } \\
\text { (g) }\end{array}$ & $\begin{array}{l}\text { Material recovered } \\
\text { from disseminator } \\
\text { (g) }\end{array}$ & Location & $\begin{array}{l}\text { Additional Cd load to soil }(\mu \mathrm{g} \mathrm{Cd} / \mathrm{g} \\
\text { soil DM, or related to FR } 370)\end{array}$ & $\begin{array}{l}\text { Area above legal } \\
\text { maximum concentration* }\end{array}$ \\
\hline \multicolumn{6}{|c|}{ Programme 1/54: assessment of fallout of fluorescent powder emitted from the Stanford type aerosol generator: } \\
\hline 353 & 367 & 302 & RAF Beaulieu airfield (Hampshire) & $2.5(180 \dagger)$ & $10 \times 2.5(138 \times 25 \dagger) \mathrm{m}$ \\
\hline $405 \S$ & 1) 736 & 5 & RAF Beaulieu airfield & 0.1 & None \\
\hline & 2) 489 & 110 & & 1.6 & None \\
\hline \multicolumn{6}{|c|}{ Programme 17/53: long distance travel of particulate clouds: } \\
\hline 370 & 3462 & 507 & RAF Beaulieu airfield & 3.3 & $4 \times 2 \mathrm{~m}$ \\
\hline 371 & 2291 & 1032 & RAF Beaulieu airfield & $\begin{array}{l}54 \% \text { and } 27 \% \text { of emissions in FR No } \\
370 \text { at } 40 \text { and } 80 \mathrm{~km} \text { from source }\end{array}$ & Probably none \\
\hline 372 & 3106 & 409 & Porton & $46 \%$ of emissions in FR 370 & Probably none \\
\hline 373 & 3031 & 343 & RAF Yatesbury & $40 \%$ of emissions in FR 370 & Probably none \\
\hline 382 & 2227 & 709 & $\begin{array}{l}\text { A35, A351 and B3075 near } \\
\text { Blandford, Salisbury } \ddagger\end{array}$ & $\begin{array}{l}56 \% \text { and } 39 \% \text { of in FR } 370 \text { at } 40 \text { and } \\
80 \mathrm{~km} \text { from source }\end{array}$ & Probably none \\
\hline 388 & 2959 & 355 & RAF Hullavington, $\mathrm{Nr}$ Chippenham & $\mathrm{ZnCdS}$ cloud missed samplers & Probably none \\
\hline 392 & 2345 & 337 & $\begin{array}{l}4 \text { Miles of minor roads near Frome, } \\
\text { Somerset }\end{array}$ & $\begin{array}{l}30 \% \text { and } 15 \% \text { of emissions in FR } 370 \\
\text { at } 40 \text { and } 80 \mathrm{~km} \text { from source }\end{array}$ & Probably none \\
\hline
\end{tabular}

${ }^{*}$ Assuming critical addition is about $85 \mu \mathrm{g} / \mathrm{cm}^{2}$, which is roughly equal to $+2.3 \mathrm{mg} / \mathrm{kg}$ soil DM, assuming baseline soil concentration is $0.7 \mathrm{mg} / \mathrm{kgDM}$. †There is confusion in the report over units. The higher values refer to the unlikely assumption that the units are $\mu \mathrm{g} /$ Petri $\mathrm{dish}$, rather than $\mathrm{mg} / \mathrm{m}^{2}$. $\ddagger$ Dispersion over distance from vehicle.

$\S$ Comparison between two disseminators.

For the long range trials, total ZnCdS disseminated was estimated from dissemination rate and trial duration. The theoretical inhaled dose at the sampling point with maximum particle count (the dose received by a person at that point during the passage of the particle cloud) was calculated from the number of inhaled particles. The following assumptions were made: the breathing rate of an active adult is 16.6 $1 / \mathrm{min},{ }^{1}$ the number of particles/g is $1.7 \times 10^{10},{ }^{11}{ }^{20}$ there was a $50 \%$ loss of fluorescence in particles due to exposure to sunlight, $^{38}$ and the ZnCdS was prepared from $60 \% \mathrm{ZnS}$ and $40 \% \mathrm{CdS}(31 \% \mathrm{Cd}) .^{38}$

\section{RESULTS}

About 51 trials were conducted from ground based sources, mostly at Porton and local airfields, with an estimated total of $250 \mathrm{~kg} \mathrm{ZnCdS}$ disseminated (table 1). Calculations of maximum fallout are based on $20000 \mu \mathrm{g} /$ petri dish $(90 \mathrm{~mm}$ diameter), the highest concentration reliably recorded. ${ }^{40}$ This concentration was found only in one trial ${ }^{1}$ and equates to 110 $\mu \mathrm{g} / \mathrm{cm}^{2}$.

A total of 42 trials with dissemination by air are documented, of which 29 took place over land, 11 over the sea, and two over both land and sea (table 2). The amount of $\mathrm{ZnCdS}$ disseminated could be calculated for 35 of the 42 trials, with a mean of $70 \mathrm{~kg}$, range $5-139 \mathrm{~kg}$, and a total amount disseminated in 35 trials of $2446 \mathrm{~kg}$.

The highest particle count (4315) was found at Dorchester after dissemination over the English Channel in 1959, with $127 \mathrm{~kg}$ ZnCdS released from a Venturi operated dispenser mounted in a Valetta aircraft, with the flight path finishing close inshore just south of Swanage. Counts over 1000 were also recorded over Cardington in August 1957 (particle count $=3403$ ) and November 1957 (1070), and at Silloth (1591), the start of a flight path over northern England and the North Sea.

There were nine trials with dissemination from ships (table 3). The highest particle count (1676) was recorded at Dorchester when $11 \mathrm{~kg}$ ZnCdS was discharged 18 miles south of Portland Bill. The second set of trials, conducted in the English Channel in January 1963, concerned the penetration of ships by aerosol, and no land based monitoring was conducted. In total $250 \mathrm{~kg} \mathrm{ZnCdS}$ was released from nine trials.

An estimated $2700 \mathrm{~kg}$ was released from 35 air disseminated and nine ship disseminated trials, and $250 \mathrm{~kg}$ from land based trials. Assuming that the mean of $70 \mathrm{~kg}$ was released from each of the seven undocumented long range trials, an estimated $3450 \mathrm{~kg}$ was disseminated in total. The programmes dated 1960-4, for which further data are not available, are summarised in table 4 . Altogether 28 trials were proposed, but three were small and are not considered further. Proposed release of ZnCdS in the remaining 25 trials was $1387 \mathrm{~kg}$. Assuming these trials took place, this would have resulted in a total ZnCdS disseminated during 8 years of about $4850 \mathrm{~kg}$ ( $1503 \mathrm{~kg} \mathrm{Cd}$ )

The largest estimated dose received by any person during any one trial was $0.42 \mu \mathrm{g} \mathrm{ZnCdS}(0.13 \mu \mathrm{g} \mathrm{Cd}$ ) (table 2). Assuming a total of 76 long range dissemination trials (51 trials in tables 2 and 3 and 25 trials in table 4), and a "worst case" assumption that at each trial a person received the maximum dose $(0.13 \mu \mathrm{g} \mathrm{Cd}$, calculated from the Dorchester measurements), then the maximum total dose over an 8 year period was about $10 \mathrm{\mu g} \mathrm{Cd}$

\section{DISCUSSION}

Zinc cadmium sulfide is a sintered, crystalline compound the photosensitivity of which makes it useful for photography, and it is thought to be safe in this role. ${ }^{41}$ However, Cd accumulates in the body, especially in the kidneys and to a lesser extent in the liver. There is uncertainty about the fate of ZnCdS when it is breathed deep into the lungs. Cadmium ions are carcinogenic in the alveolar cells, but the insolubility of ZnCdS probably reduces this potential. About 5\% of ingested $\mathrm{Cd}^{42}$ and up to $57 \%$ of inhaled $\mathrm{Cd}^{43}$ is absorbed, bound to albumen or to metallothionein. Initially stored in the liver, Cd metallothionein enters the kidneys, where the lysosomes in the proximal tubules release the $\mathrm{Cd}$, impairing tubule function. The estimated 1.5 tonnes total Cd dissemination by the Ministry of Defence compares with an estimated 15 tonnes $\mathrm{Cd}$ released into the atmosphere from United Kingdom industry annually. ${ }^{44}$ Thus, the United Kingdom trials increased the atmospheric Cd load by about $1.2 \%$.

The estimated maximum inhaled dose from any one trial was $0.13 \mu \mathrm{g} \mathrm{Cd}$, which is several orders of magnitude lower than the $\mathrm{Cd}$ concentration in air $(100 \mu \mathrm{g} C d / 1)$ required to cause lung damage in mammals. ${ }^{45}$ Our "worst case" estimate of cumulative personal dose received from all trials was about $10 \mu \mathrm{g}$, which is of the same order as the estimated total Cd inhalation in North American cities affected by the tests (24.4, 14.5, and $6.8 \mathrm{\mu g}$ in St Louis, Winnipeg, and Minneapolis, respectively). 
Table 2 Trials of dissemination from aircraft, and estimated theoretical inhaled dose of $\mathrm{ZnCdS}$ at the sampling point with maximum particle count

\begin{tabular}{|c|c|c|c|c|c|c|}
\hline Report & Date of trial & $\begin{array}{l}\text { Approximate } \\
\text { amount } \\
\text { released }(\mathrm{kg})\end{array}$ & Location & $\begin{array}{l}\text { Maximum } \\
\text { particle } \\
\text { count }\end{array}$ & $\begin{array}{l}\text { Sampling } \\
\text { rate (I/min) }\end{array}$ & $\begin{array}{l}\text { Estimated } \\
\text { inhaled } \\
\text { dose }(\mu \mathrm{g})^{*}\end{array}$ \\
\hline \multirow[t]{2}{*}{ FR 504} & 11 September 1956 & 12 & Porton & 351 & $17.5 \dagger$ & 0.039 \\
\hline & 17 September 1956 & 111 & North Sea & 93 & 17.5 & 0.010 \\
\hline FR 514 & 25 April 1957 & 138 & North Sea & 337 & 22 & 0.030 \\
\hline FR 516 & 28 August 1957 & 5 & Cardington & 3403 & 20 & 0.332 \\
\hline FR 515 & 13 November 1957 & 117 & North Sea & 112 & 10 & 0.022 \\
\hline \multirow[t]{2}{*}{ PTP 633} & 14 November 1957 & ** & Cardington & 999 & 20 & 0.010 \\
\hline & 15 November 1957 & ** & Cardington & 1070 ฯ & 20 & 0.104 \\
\hline PN 68 & 22 July 1958 & 98 & Irish Sea & 415 & 20 & 0.041 \\
\hline PN 138 & 18/19 September 1958 & 116 & English Channel & 674 & 20.5 & 0.064 \\
\hline PN 139 & 28 October 1958 & 120 & English Channel & 669 & 20.5 & 0.064 \\
\hline PN 145 & 11 December 1958 & 83 & North Sea & 144 & 20.5 & 0.014 \\
\hline PN 185 & 14 April 1959 & 123 & English Channel & 182 & 20.5 & 0.017 \\
\hline PN 186 & 26 May 1959 & 139 & North Sea and NE England & 1591 & 21.5 & 0.145 \\
\hline PN 187 & 7 July 1959 & 139 & English Channel \& Cornwall & 123 & 20 & 0.012 \\
\hline PN 188 & 18 August 1959 & 127 & English Channel & 4315 & 20 & 0.421 \\
\hline \multirow[t]{4}{*}{ PN 253} & 19 March 1958 & ** & Cardington & ** & ** & \\
\hline & 4 March 1959 & ** & Cardington & ** & ** & \\
\hline & 7 May 1959 & ** & Cardington & ** & ** & \\
\hline & 9 September 1960 & ** & Cardington & ** & ** & \\
\hline \multirow[t]{10}{*}{ PN 134} & 29 May 1959 & 45 & Cardington & $96 \pi$ & 20 & 0.009 \\
\hline & 3 June 1959 & 45 & Cardington & $44 \pi$ & 20 & 0.004 \\
\hline & 25 August 1959 & 45 & Cardington & $17 \pi$ & 20 & 0.002 \\
\hline & 15 September 1959 & 45 & Cardington & 1299 & 20 & 0.013 \\
\hline & 16 September 1959 & 45 & Cardington & $34 \pi$ & 20 & 0.003 \\
\hline & 17 September 1959 & 45 & Cardington & $\ddagger$ & 20 & \\
\hline & 18 September 1959 & 45 & Cardington & $\ddagger$ & 20 & \\
\hline & 22 September 1959 & 45 & Cardington & $8 \pi$ & 20 & 0.001 \\
\hline & 23 September 1959 (1 st) & 45 & Cardington & 278 व & 20 & 0.027 \\
\hline & 23 September 1959 (2nd) & 45 & Cardington & 2719 & 20 & 0.026 \\
\hline \multirow[t]{9}{*}{ PN 183} & 21 April 1960 & 17.5 & Cardington & 2099 & 20 & 0.020 \\
\hline & 25 May 1960 & 17.5 & Cardington & $143 \pi$ & 20 & 0.014 \\
\hline & 26 May 1960 (1st) & 17.5 & Cardington & $285 \pi$ & 20 & 0.028 \\
\hline & 26 May 1960 (2nd) & 17.5 & Cardington & $315 \pi$ & 20 & 0.031 \\
\hline & 26 May 1960 (3rd) & 17.5 & Cardington & $157 \pi$ & 20 & 0.015 \\
\hline & 17 June 1960 & 91 & Cardington & 387 & 20 & 0.038 \\
\hline & 29 June 1960 & 91 & Cardington & 30 & 20 & 0.003 \\
\hline & 30 June 1960 & 91 & Cardington & 87 & 20 & 0.008 \\
\hline & 1 July 1960 & 91 & Cardington & 36 & 20 & 0.004 \\
\hline \multirow{2}{*}{ PTP 764} & 27 October 1960 & 74 & English Channel & $2 \S$ & 21.3 & 0.000 \\
\hline & 28 October 1960 & 74 & English Channel & $91 \S$ & 19.8 & 0.009 \\
\hline \multirow{2}{*}{$\begin{array}{l}\text { Programme } \\
17 / 60 / \text { PFTR } 610+\dagger \\
\text { PFTR 610tt }\end{array}$} & ** & ** & Salisbury & ** & $* *$ & \\
\hline & 28 March 1963 & 68 & Norwich & 377 & 10 & 0.074 \\
\hline \multicolumn{7}{|c|}{ 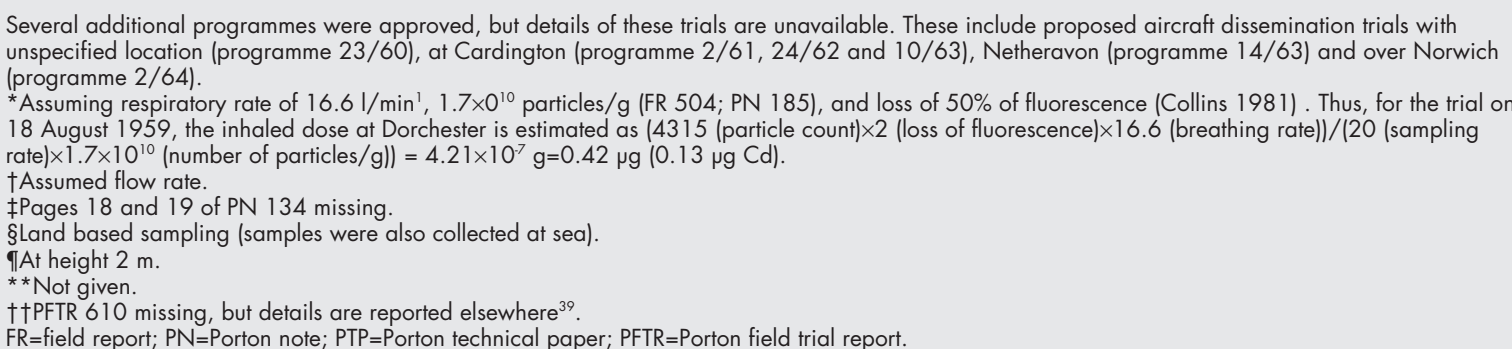 } \\
\hline
\end{tabular}

The National Research Council estimated that the average yearly inhalation dose of Cd from other sources was 30-250 $\mu g$, with smoking adding $2-4 \mu g / 20$ cigarettes. ${ }^{1}$ Thus, the "worst case" dose in the United Kingdom equated to the amount of Cd inhaled in an urban environment in 12-100 days, or from smoking about 100 cigarettes.

Being insoluble, CdS has a lower bioavailability when inhaled than soluble Cd compounds. ${ }^{46}$ However, the possibility of photodegradation of a proportion of the ZnCdS to soluble forms - such as $\mathrm{ZnCdSO}_{4}$ - cannot be ruled out. Assuming renal accumulation of $35 \%$ of Cd cleared by the lungs, and lung clearance of $56 \%$ of inhaled $\mathrm{Cd}^{46}$ a $10 \mu \mathrm{g}$ inhaled dose could result in an additional renal burden of about $2 \mu \mathrm{gd}$. As the currently accepted critical limit of $\mathrm{Cd}$ in the renal cortex is $200 \mu \mathrm{g} / \mathrm{g},{ }^{47}$ any additional renal burden was negligible.
The immediate contamination from ground based dissemination was probably not a serious problem as most releases were on airfields, which were not used for food production. There are two perceived risks of long term soil contamination, to garden plants subsequently grown on the site which may accumulate and contaminate consumers, and to children consuming contaminated soil. No long term adverse effects through garden plants have been established from Cd contaminated garden soil at Shipham. ${ }^{48}$

United Kingdom regulations for sewage sludge application provide guidance on safe $\mathrm{Cd}$ concentrations in soils. ${ }^{49} \mathrm{Up}$ to 3 $\mu \mathrm{g} \mathrm{Cd} / \mathrm{g}$ soil dry matter in the top $20 \mathrm{~cm}$ is permitted, with a maximum deposition of $1.5 \mu \mathrm{g} \mathrm{Cd} / \mathrm{cm}^{2} / 10$ years. The deposition rate of $110 \mu \mathrm{g} / \mathrm{cm}^{2}$ at Beaulieu exceeds this limit, but is not illegal as it does not arise from sewage. Assuming a soil bulk 
Table 3 Trials of dissemination from ships, and estimated theoretical inhaled dose of $\mathrm{ZnCdS}$ at the land based sampling point with maximum particle count

\begin{tabular}{|c|c|c|c|c|c|c|}
\hline Report & Date of trial & $\begin{array}{l}\text { Approximate amount } \\
\text { released }(\mathrm{kg})\end{array}$ & Location & $\begin{array}{l}\text { Maximum } \\
\text { particle count }\end{array}$ & $\begin{array}{l}\text { Sampling rate } \\
\text { (1/min) }\end{array}$ & $\begin{array}{l}\text { Estimated inhaled dose } \\
(\mu \mathrm{g})^{*}\end{array}$ \\
\hline \multirow[t]{3}{*}{ PN 146/203 } & 7 October 1959 & 11 & English Channel & 1676 & 20.4 & 0.160 \\
\hline & 7/8 November 1959 & 93 & English Channel & 40 & 20.2 & 0.004 \\
\hline & 9/10 November 1959 & 95 & Irish Sea & 115 & 21.4 & 0.010 \\
\hline \multirow[t]{6}{*}{ PTP 893} & 28 January 1963 & 7.6 & English Channel & $\dagger$ & & \\
\hline & 28 January 1963 & 8.6 & English Channel & $\dagger$ & & \\
\hline & 29 January 1963 & 9.5 & English Channel & $\dagger$ & & \\
\hline & 29 January 1963 & 4.8 & English Channel & $\dagger$ & & \\
\hline & 30 January 1963 & 10.2 & English Channel & $\dagger$ & & \\
\hline & 30 January 1963 & 10.4 & English Channel & $\dagger$ & & \\
\hline
\end{tabular}

${ }^{*}$ Assuming respiratory rate of $16.6 \mathrm{l} / \mathrm{min}$ (NRC 1997), $1.7 \times 10^{10}$ particles/g (FR 504; PN 185) and loss of 50\% of fluorescence. ${ }^{38}$

†Land based sampling not done.

PN Porton note; PTP Porton technical paper.

density of $1.5 \mathrm{~g} / \mathrm{cm}^{3}$, the top $20 \mathrm{~cm}$ of soil contains at most an additional $3.3 \mu \mathrm{g} \mathrm{Cd} / \mathrm{g}$ dry matter from the Beaulieu test. Added to the median $\mathrm{Cd}$ soil concentration $(0.7 \mu \mathrm{g} / \mathrm{g})$, the expected maximum is $4 \mathrm{\mu g} / \mathrm{g}$ dry matter, above the permitted maximum for sewage sludge application, although the area affected was small (table 1).

The risk of soil consumption by children can be determined from the estimated lowest observed adverse effect level (to produce acute gastrointestinal symptoms) for a single dose of ingested Cd, estimated at $43 \mu \mathrm{g} / \mathrm{kg}$ body weight. ${ }^{50} \mathrm{~A} 10 \mathrm{~kg}$ child would need to eat $108 \mathrm{~g}$ dry matter of soil with $4 \mu \mathrm{g} \mathrm{Cd} / \mathrm{g}$ to reach this dose. The background intake of Cd (12-84 $\mu \mathrm{g} / \mathrm{day}$ in urban areas, 10-60 $\mathrm{gg}$ /day from food and water) is much higher than from contaminated soil.

The greatest risk of ground contamination was probably from material washed off the dispenser in the field before it was returned to headquarters, as operators were instructed that "gross contamination around the dispenser on the trailer will be brushed off and washed down before departing". However, the sites are not sufficiently precisely identified in the reports to permit remedial action, and in any case, in the intervening 35-48 years it is to be expected that some of the ZnCdS will have been subjected to chemical weathering and transmutation, broken down by bacteria, and leached from the surface soil. Any material that resisted breakdown for this period should be so insoluble as not to pose a health hazard.

A further possible risk was to four Ministry of Defence officials that operated disseminators, as the respirators may not have protected them against the particles, which had median diameter $1.5 \mu \mathrm{m}$ and density $4 \mathrm{~g} / \mathrm{cm}^{3}$. Two disseminators have survived and are in good health, one died aged 73 of a heart attack, and the final operator could not be definitively traced but is thought to be alive. The building on the Porton Range

Table 4 Approved programmes of trials $†$ of dissemination of $\mathrm{ZnCdS}$ from aircraft, 1960-4, where reports of the trials (and indication as to whether or not they took place) are unavailable

\begin{tabular}{lllcc}
\hline $\begin{array}{l}\text { Programme } \\
\text { number }\end{array}$ & $\begin{array}{l}\text { Proposed } \\
\text { location }\end{array}$ & $\begin{array}{l}\text { Trials } \\
\text { proposed }(\mathrm{n})\end{array}$ & $\begin{array}{l}\text { ZnCdS/trial } \\
(\mathrm{kg})\end{array}$ & $\begin{array}{l}\text { Total } \\
\text { amount } \\
\text { ZnCdS }(\mathrm{kg})\end{array}$ \\
\hline $23 / 60$ & Not stated & 3 & 91 & 273 \\
$2 / 61$ & Cardington & 4 & 68 & 272 \\
& Cardington & 6 & 14 & 84 \\
$24 / 62$ & Cardington & 6 & 45 & 270 \\
$10 / 63$ & Cardington & 2 & 136 & 272 \\
$2 / 64$ & Norwich & $4^{*}$ & 54 & 216 \\
& & & TOTAL & 1387 \\
\hline
\end{tabular}

*Dates of three of the four proposed trials were open to cancellation. tExcludes three proposed trials at Netheravon Airfield (programme $14 / 63$ ) where total proposed releases were $0.75 \mathrm{~kg}$.

\section{Key messages}

- The maximum possible inhaled dose as a result of the Ministry of Defence trials is small relative to background concentrations of inhaled cadmium.

- The increase in cadmium loading of soil near the points of dissemination from static land based sources is small, except in the immediate vicinity of the disseminators.

- There were no adverse effects on people operating the disseminators, who may be expected to have inhaled larger doses than the exposed population.

\section{Policy implications}

- Excessive cadmium intake has potentially harmful effects on humans, but the contribution from Ministry of Defence trials during the cold war was very small in comparison with background exposure. There is no need for public concern over the Ministry of Defence disseminations.

used for storing ZnCdS was destroyed at the end of the programme. Operators probably risked damage to eyes and exposed skin from ultraviolet light when counting ZnCdS particles, but this seemingly did not happen.

In conclusion, between 1953 and 1964, ZnCdS particles were disseminated from static sources, vehicles, ships, and aircraft by the Ministry of Defence. In long range trials, the inhaled dose during the most severe case was small $(0.13 \mu \mathrm{g}$ $\mathrm{Cd}$ ). Land based trials did not significantly add to soil $\mathrm{Cd}$, except close to the dissemination point. Risk to the public is therefore considered negligible. People involved in dissemination, who would have been exposed to large amounts of $\mathrm{Cd}$, had no ill effects.

\section{ACKNOWLEDGEMENTS}

The study was supported by the UK Ministry of Defence.

\section{Authors' affiliations}

P J Elliott, Department of Epidemiology and Public Health, Imperial College, University of London, St Mary's Campus, Norfolk Place, London W2 IPG, UK

C J C Phillips, P J Lachmann, Department of Clinical Veterinary

Medicine, University of Cambridge, Cambridge CB3 OES, UK

B Clayton, Faculty of Medicine, University of Southampton,

Southampton, UK

\section{REFERENCES}

1 National Research Council. Toxicological assessment of the Army's zinc cadmium sulfide dispersion tests. Washington, DC: National Academy Press, 1997. 
2 Titt RA. Assessment of fallout of fluorescent powder emitted from the 'Stanford' type aerosol generator (programme 1/54). 1954. Porton: Ministry of Defence, 1954. (Field report No 353.)

3 Titt RA. Assessment of fallout of fluorescent powder emitted from the Stanford type aerosol dispenser (programme 1/54). 1954. Porton: Ministry of Defence, 25 October 1954. (Field report No 405.)

4 Titt RA. The long distance travel of particulate clouds (programme 17/53). Porton: Ministry of Defence, 13 July 1954. (Field report No 370.)

5 Titt RA. The long distance travel of particulate clouds (programme 17/53). Porton: Ministry of Defence, 8 June 1954. (Field report No 371.)

6 Titt RA. The long distance travel of particulate clouds (programme 17/53). Porton: Ministry of Defence, 13 July 1954. (Field report No 372.)

7 Titt RA. The long distance travel of particulate clouds (programme 17/53). Porton: Ministry of Defence, 13 July 1954. (Field report 373.

8 Titt RA. The long distance travel of particulate clouds (programme 17/53). Porton: Ministry of Defence, 13 July 1954. (Field report No 382.)

9 Trouern-Trend $\mathbf{K}$. The long distance travel of particulate clouds (programme 17/53). Porton: Ministry of Defence, 6 August 1954. (Field report No 388.)

10 Titt RA. The long distance travel of particulate clouds (programme 17/53). Porton: Ministry of Defence, 24 August 1954. (Field report No 392.)

11 Titt RA. The long distance travel of particulate clouds (programme $35 / 56$ ). Porton: Ministry of Defence, 5 May 1957. (Field report No 504.)

12 Wheeler CL. The long distance travel of particulate clouds (programme 1/57). Porton: Ministry of Defence, 2 January 1958. (Field report No 514.)

13 Titt RA. Determination of particle size in a cloud of FP produced by a Venturi dispenser mounted in a Valette aircraft (programme 19/57).Porton: Ministry of Defence, 6 February 1958. (Field report No 516.)

14 Wheeler CL. The long distance travel of particulate clouds (programme 1/57). Porton: Ministry of Defence, 5 February 1958. (Field report No 515.)

15 Jones JIP, Butler HE. Some measurements of the vertical distribution of particles at about 50 miles from a source. Porton: Ministry of Defence, 20 March 1958. (Porton technical paper No 633.)

16 Titt RA, Laird A. Long distance travel of particulate clouds. Porton: Ministry of Defence, 23 January 1959. (Porton note No 68.)

17 Collins GF, Laird AR. Long distance travel of particulate clouds (programme 10/58). Porton: Ministry of Defence, 29 February 1960. (Porton note No 138.

18 Collins GF, Laird AR. Long distance travel of particulate clouds (programme 10/58). Porton: Ministry of Defence, 26 February 1960. (Porton note No 139.)

19 Titt RA. Long distance travel of particulate clouds (programme 10/58). Porton: Ministry of Defence, 24 March 1960. (Porton note No 145.)

20 Collins GF, Laird AR. Long distance travel of particulate clouds (programme 10/58). Porton: Ministry of Defence, 26 January 1961. (Porton note No 185.)

21 Laird AR, Titt RA. The long distance travel of particulate clouds (programme 10/58). Porton: Ministry of Defence, 26 January 1961. (Porton note No 186.)

22 Laird AR, Titt RA. The long distance travel of particulate clouds (programme 10/58). Porton: Ministry of Defence, 1 March 1961 (Porton note No 187.)

23 Laird AR, Titt RA. The long distance travel of particulate clouds (programme 10/58). Porton: Ministry of Defence, 30 January 1961. (Porton note No 188.)

24 Collins GF. Experimental dispensers for fluorescent powder. Porton: Ministry of Defence. Undated. (Porton note No 253.)

25 Thompson N. The vertical diffusion of particulate clouds over medium distances of travel: preliminary results from trials carried out in 1959. Porton: Ministry of Defence, 1959. (Porton note No 134.)

26 Thompson $\mathbf{N}$. The vertical diffusion of particulate clouds over medium distances of travel: results from trails carried out in. Porton: Ministry of Defence, 15 December 1960. (Porton note No 183.)
27 Titt RA. A preliminary study of the vulnerability of ships to BW attacks at sea. Porton: Ministry of Defence, 17 March 1961. (Porton technical paper No 764.)

28 Titt RA, Bradshaw AE, Wheeler CL. The travel of aerosols by night and the influence of topography upon the dosage including penetration into built-up areas (programme No 17/60). Porton: Ministry of Defence, 10 August 1960

29 Collins GF, Banfield JN. The penetration of built-up areas by aerosols at night (programme 2/63). Porton: Ministry of Defence, 7 May 1964. (Porton field trial report No 610.)

30 Titt RA. Large area coverage by aerosol clouds generated at sea (programme 6/59). Porton: Ministry of Defence, 24 March 1960. (Porton note No 146.)

31 Collins GF, Laird AR, Titt RA. Large area covered by aerosol clouds generated at sea. Porton: Ministry of Defence, 22 March 1961. (Porton note No 203.)

32 Collins GF, Banfield JN. The vulnerability of ships at sea to BW aerosol attack. Porton: Ministry of Defence, 7 February 1964. (Porton technical paper No 893.)

33 Trouern-Trend K, Bradshaw AE, Wheeler CL. Travel of particulate clouds: release of FP above friction layer (programme 23/60). Porton: Ministry of Defence, 7 November 1960.

34 Thompson N, Barker A, Wheeler CL. The vertical diffusion of particulate clouds over medium distances of travel (programme 2/61). Porton: Ministry of Defence, 20 January 1961.

35 Farley GG. Check of sampling and assessment technique in trials employing FP tracer (programme No 24/62). Porton: Ministry of Defence, 15 January 1964.

36 Collins GF, Bradshaw AE, Musty JWG. Comparison of FP dosages measured by drum impactors and millipore filters after different distances of cloud travel (programme No 10/63). Porton: Ministry of Defence, 17 September 1963.

37 Banfield JN, Bradshaw AE, Musty JWG. The penetration of built-up areas by aerosols at night (programme 2/64). Porton: Ministry of Defence, 1 January 1964

38 Collins GF. A review of the use of zinc cadmium sulphide (FP) in particulate diffusion studies (UC). DERA/CBD/TR990184/1.0, 1981. (Reprinted 1999). Porton: Ministry of Defence, 1999.

39 Carter GB. Zinc cadmium sulphide (fluorescent particles) field trials conducted by the UK: 1953-1964 (UC) ). DERA/CBD/CR990004/1.0 Porton: Ministry of Defence. 1999.

40 Titt RA. The long distance travel of particulate clouds. Porton: Ministry of Defence, 1954. (Field report No 370.)

41 Patterson MH, Turner AK, Sadeghi M. Health, safety and environmental aspects of the use of cadmium compounds in thin-film PV modules. Solar Energy Materials and Solar Cells 1994;35:305-10.

42 Rambeck WA. Influences on the carry over of cadmium in the food chain. Proceedings of the Society of Nutrition Physiology 1994;2:23-9.

43 Kiellstrom T, Nordberg, GF. A kinetic model of cadmium metabolism in the human being. Environ Res 1978;16:248-69.

44 Johnston $\mathbf{A E}$, Jones KC. The origin and fate of cadmium in soil. Peterborough: The Fertiliser Society, 1995. (Proc No 366.)

45 Rusch GM, O'Grodnick JS, Reinhat WE. Acute inhalation study in the rat of comparative uptake, distribution and excretion for different cadmium containing materials. Am Ind Hyg Assoc J 1986;47:754.

46 Klimisch $\mathbf{H}-\mathbf{J}$. Lung deposition, lung clearance and renal accumulation of inhaled cadmium chloride and cadmium sulphide in rats. Toxicol 1993;84:103-24.

47 Roels HA, Lauwerys RR, Buchet JP, et al. In vivo measurement of liver and kidney cadmium in workers exposed to this metal: its significance with respect to cadmium in blood and urine. Environ Res 1981;26:217-40

48 Elliott P, Arnold R, Cockings S, et al. Risk of mortality, cancer incidence, and stroke in a population potentially exposed to cadmium. Occup Environ Med 2000;57:94-7.

49 Her Majesty's Service Overseas. Sludge (Use in Agriculture) Regulations 1989 (SI 1989 No 1790), amended 1990 (SI 1990 No 880). London: The Stationery Office 1990.

50 Nordberg G. Excursions of intake above ADI: case study on cadmium. Reg Toxicol Pharmacol 1999;30:S57-62. 